\title{
TEKNIK PENERAPAN BERPIKIR KRITIS BAGI SEORANG PERAWAT
}

\author{
Indah Karina Milala : 181101010 \\ Email : indahkarina2001@gmail.com
}

\begin{abstract}
Abstrak
Berpikir merupakan cara atau aktivitas dalam mencari ide atau gagasan yang kreatif dan berinofasi untuk mencari informasi yang nyata dan masuk akal. Berpikir dapat diartikan juga sebagai menimbang dan memutuskan sesuatu hal. Berpikir juga dilakukan untuk memahami realitas dalam rangka mengambil keptusan dalam memecahkan masalah dan menghasilkan sesuatu yang baru atau kreativitas dari ide tersebut. Berpikir Kritis adalah proses yang bermanfaat dimana sangat bertujuan dalam mendapat tentang kejadian atau fakta yang dapat disimpulkan tentang adanya perspektik atau pandangan baru. Sebagai perawat merupakan bagian dari pemberi pelayanan kesehatan, yaitu pemberi asuhan keperawatan dengan menggunakan proses dalam keperawatan akan dituntut untuk berpikir kritis didalam berbagai situasi saat berada di Rumah Sakit baik dalam kondisi baik ataupun tidak baik.
\end{abstract}

Kata Kunci : Berpikir Kritis,Tehnik Berpikir,Karakteristik Berpikir Kritis

\section{Latar Belakang}

Dalam kemampuan berpikir kritis yang sangat penting dan bermanfaat bagi seorang perawat dalam kehidupan lingkungan dalam pekerjaan dan berfungsi sangat efektif dalam semua aspek kehidupan. Berpikir kritis juga merupakan suatu tehnik berpikir yang sangat melatih kemampuan dalam melakukan pengkajian kita dalam menentukan keputusan atas dasar gagasan ide yang bersifat nyata dan fakta dari yang kita lihat dan alami. Begitu hal nya dengan seorang perawat sebagai pemberi layanan kepada pasien yang berada di Rumah sakit atau dimanapun harus menerapkan sistem tehnik berpikir kritis dalam memberikan asuhan keperawatan pada pasien yang dia rawat dengan adanya sistem berpikir kritis perawat dapat menilai atau menganalisa secara rasional sehingga dapat merumuskan kesimpulan dan dapat mengambil keputusan untuk melakukan tindakan dalam proses pengkajian tersebut. Berpikir kritis juga sangat mempengaruhi perawat dalam melakukan tugasnya saat berada di rumah sakit perawat dianjurkan untuk berpikir secara kritis sebelum melakukan tindakan proses asuhan keperawatan untuk merawat pasien. 


\section{Tujuan}

Berpikir kritis memiliki tujuan yang begitu bermanfaat bagi seorang perawat dimana dalam berpikir kritis bertujuan untuk mengetahui hubungan berpikir kritis bagi pelayanan dalam asuhan keperawatan, untuk mengetahui tehnik-tehnik yang digunakan dalam berpikir kritis. Selain itu Berpikir kritis juga memiliki tujuan yaitu untuk bisa memecahkan masalah dan menyimpulkan setiap masalah yang ada dalam dunia kesehatan seperti bagi seorang perawat sangat dibutuhkan adanya pengetahuan tehnik berpikir kritis saat berada di rumah sakit maupun di lapangan saat memberikan pelayanan kepada pasien.

\section{Metode}

Dalam kajian ini jenis yang di gunakan adalah dengan metode Literasi yaitu dengan metode membaca dari sumber buku tentang keperawatan, ebook dan jurnal. Dengan metode ini saya dapat mengetahui tentang tehnik berpikir kritis bagi seorang perawat,karakteristik berpikir kritis,proses berpikir kritis serta aplikasi berpikir kritis dalam keperawatan.
Dengan cara membandingkan dari jurnal dan buku yang terkait dengan berpikir kritis bagi seorang perawat.

\section{Hasil}

Hasil dari kajian yang didasarkan pada sumber buku tentang berpikir kritis yang merupakan bagian sangat penting dilakukan sebelum mengambil keputusan dalam asuhan keperawatan karena merupakan salah satu metode ilmiah dalam menyelesaikan masalah klien atau pasien. Dalam hal ini diperlukan kemampuan perawat mengidentifikasi masalah klien dan memilih solusi intervensi yang tepat tidak lepas dari kemampuan perawat berfikir kritis untuk mengali berbagai alasan berdasarkan solusi yang teridentifikasi. Untuk berfikir kritis dalam menghadapi setiap masalah dan pengalaman baru yang menyangkut pasien harus diperlukan adanya proses berfikir kritis saat melakukan tindakan asuhan keperawatan saat berada di Rumah Sakit perawat mampu mengidentifikasi atau mengkaji masalah tersebut dengan teliti. Oleh karena itu dalam proses berfikir kritis ini perawat perlu mengetahui dan memiliki wawasan yang luas tentang berfikir kritis agar dalam melakukan tindakan 
asuhan keperawatan perawat tidak melakukan kesalahan. Untuk berpikir kritis perawat harus mengembangkan dengan memiliki karakteristik percaya diri,berfikir mendalam,keadilan,tanggung jawab dan akuntabilitas,mengambil resiko,diiplin,kegigihan,kreatif,rasa ingin tahu,integritas dan rendah hati,dimana karakteristik tersebut dapat dilihatdari sikap dalam memberikan asuhan keperawatan dari keterlibatan,kedewasaan untuk mengontrol emosi dan inovasi (Deswani 2010)

\section{Pembahasan}

Berpikir kritis adalah proses pengujian secara rasional terhadap kesimpulan,pendapat,prinsip,pemikiran, masalah,kepercayaan dan tindakan yang harus dilakukan perawat dalam proses merawat klien. Berpikir kritis juga sebagai suatu tehnik berpikir yang melatih kemampuan dalam mengevaluasi atau melakukan penilaian secara cermat tentang tepat tidaknya ataupun layak tidaknya suatu gagasan. Selain itu berpikir kritis juga merupakan suatu proses berpikir (kognitif) yang mencakup penilaian dan analisis secara rasional tentang semua informasi,masukan,pendapat,dan ide. Kemudianmerumuskan kesimpulan dari masalah tersebut serta mengambil keputusan yang tepat. Dalam hal ini perawat yang sebagai pelaksana berpikir kritis untuk merawat klien saat berada di Rumah Sakit sebelum melakukan tindakan kepada pasien perawat harus menerapkan sikap berpikir kritis secara tepat dan benar agar tidak terjadi kesalahan yang berakibat merugikan pasien.

Rasional dan beralasan, yang artinya argumen yang diberikan berdasarkan analisis mempunyai data yang tepat. Reflektif, artinya bahwa asumsi atau persepsi dalam berpikir atau mengambil keputusan. Kemandirian Berpikir, yang artinya tidak pasif dalam menerima pemikiran dan keyakinan orang lain dengan memutuskan secara tepat dan benar. Berpikir Kreatif, artinya perawat harus menggunakan keterampilan intelektualnya untuk menciptakan pemikiran yang baru dan kreatif. Berpikir adil dan terbuka, yang artinya merubah dari pemikiran yang salah untuk menjadi yang benar dan lebih baik. Pengambilan keputusan berdasarkan keyakinan, artinya mengambil kepetusan atau 
mengevaluasi suatu argumentasi dan menyimpulkannya.

Dalam proses berpikir kritis sebagai perawat harus menerapkan sikap penggunaaan bahasa yang baik saat berkomunikasi dengan klien dimana perawat harus menggunakan kata-kata verbal dan non verbal dengan tepat. Selain itu dalam berpikir kritis sebagai perawat harus mampu menyimpulkan saat mengidentifikasi suatu masalah pengkajian proses asuhan keperawatan saat berada di Rumah sakit perawat mampu berpikir kritis dengan argumentasi dalam memberi alasan yang jelas.
Tehnik dalam berpikir kritis yang harus diterapkan sebagai perawat yaitu dengan cara: Berpikir Autistik, yaitu berpikir dengan cara berpikir yang mengkhayal seperti memikirkan sesuatu yang berinovasi. Berpikir Realistik, yaitu berpikir yang dilakukan dengan tehnik melihat situasi yang nyata dimana berpikir realistik berpikir dengan cara melihat kondisi yang langsung dan dapat menyimpulkan dengan tepat dan jelas. Berpikir Kreatif, yaitu tehnik berpikir yang dilakukan seperti berpikir dengaan cara menemukan gagasan atau ide sesuatu yang baru serta kreatif dan bermanfaat.

Dalam berpikir kritis yang diterapkan oleh perawat untuk melakukan asuhan keperawatan di Rumah sakit memiliki sifat yang paling penting untuk proses berpikir kritis secara rasional dimana sebagai perawat memiliki kepercayaan diri untuk pengambilan keputusan yang benar dalam konteks klinis dan untuk proses penilaian terkait masalah yang sedang terjadi dalam melaksanakan tindakan yang cepat maka diperlukan keputusan untuk mencari kesimpulan yang baik sesuai tindakan yang dilaksanakan dengan begitu perawat harus menerapkan tehnik berpikir kritis. 
Penutup

Dalam hal ini Berpikir kritis sangat berperan penting bagi seorang perawat atau dengan kata lain tidak dapat dipisahkan karena berpikir kritis sangat berpengaruh dalam proses keperawatan atau asuhan keperawatan dalam tindakan berpikir kritis perawat harus mampu mengambil keputusan atau menyimpulkan suatu masalah saat berada dalam proses pengkajian seperti mencari data data pasien atau klien diperlukan pengkajian yang secara rasional bersifat fakta sehingga perawat dapat mengambil keputusan secara tepat sesuai dengan bukti yang ada sehingga dalam proses berpikir kritis ini perawat berhasil dalam melakukan tindakan.

Oleh karena itu berpikir kritis ini berkaitan erat dengan perawat dalam melaksanakan tindakan nya saat berada di Rumah Sakit.

\section{Daftar Pustaka}

Agil Maizar, Yenita Agus. (2017, Juli). Gambaran Berpikir Kritis Dalam Problem Based learning (PBL) Mahasiswa Keperawatan FKIK UIN Syarif Hidayatullah. Jurnal Keperawatan, 10-18.

Deniati Kiki,Anugrahwati Ria,Suminarti Tini. (2018). Pengaruh Bepikir Kritis Terhadap Kemampuan Perawat pelaksana Dalam
Melakukan Asuhan

Keperawatan Di Rumah Sakit Hermina Bekasi Tahun 2016. Jurnal Kesehatan Holistik, 12, 21-25.

Deswani. (2009). Proses Keperawatan dan Berpikir Kritis. Jakarta: Salemba Medika.

Fathi, A., \& Simamora, R. H. (2019, March). Investigating nurses' coping strategies in their workplace as an indicator of quality of nurses' life in indonesia: a preliminary study. In IOP Conference Series: Earth and Environmental Science, (Vol. 248, No. 1, p. 012031). IOP Publishing.

Fisher. (2008). Berfikir Kritis Sebuah Pengantar. Jakarta: Erlangga.

Hidayat, A.A.A. (2011). Pengantar Konsep Dasar Keperawatan (2 ed.). Jakarta: Salemba Medika.

Indriatie. (2013, Agustus 2). Berpikir Kritis Dalam Proses Keperawatan. keperawatan, 6, 89-93.

Jurnal

Kozier,Barbara. (2010). Buku Ajar Fundamental Keperawatan; Konsep,Proses dan Praktik (7 ed.). Jakarta: EGC.

Mardella Eka Anisa,Devi Yulianti. (2014). Buku Ajar Keperawatan Dasar. Jakarta: EGC.

Maryam Siti,Setiawati Santun,Ekasari Fatma Mia. (2007). Buku Ajar Berpikir Kritis dalam Proses Keperawatan. Jakarta: EGC.

Mulyaningsih. (2013, November). Peningkatan Caring Melalui Kemampuan Berpikir Kritis perawat. Jurnal Managemen Keperawatan, 1, 100-106.

Nursalam. (2011). Manajemen Keperawatan (3 ed.). Jakarta: Salemba Medika. 
Sudono,B, \& dkk. (2017, April). Gambaran Kemampuan Berpikir Kritis Perawat Primer dalam Pelaksanaan di Rumah Sakit Islam Surakarta. Jurnal IImu Keperawatan Indonesia, 10, 79-106.
Sumijatun. (2010). Konsep Dasar Menuju keperawatan Profesional. Jakarta: Tran Info Media. 